\title{
Current Challenges in Understanding the Cellular and Molecular Mechanisms in Niemann-Pick Disease Type C1
}

\author{
Anja U. Bräuer 1,2 ${ }^{1}$, Angela Kuhla ${ }^{3,4}$, Carsten Holzmann ${ }^{4,5} \mathbb{D}$, Andreas Wree 4,6 \\ and Martin Witt $4,6, *$ (D) \\ 1 Research Group Anatomy, School of Medicine and Health Sciences, Carl von Ossietzky University \\ Oldenburg, D-26129 Oldenburg, Germany \\ 2 Research Center for Neurosensory Science, Carl von Ossietzky University Oldenburg, \\ D-26129 Oldenburg, Germany \\ 3 Institute for Experimental Surgery, Rostock University Medical Center, Schillingallee 69a, \\ 18057 Rostock, Germany \\ 4 Center of Transdisciplinary Neuroscience Rostock, D-18147 Rostock, Germany \\ 5 Institute of Medical Genetics, Rostock University Medical Center, D-18057 Rostock, Germany \\ 6 Institute of Anatomy, Rostock University Medical Center, D-18057 Rostock, Germany \\ * Correspondence: martin.witt@med.uni-rostock.de; Tel.: +49-381-494-8435
}

Received: 26 August 2019; Accepted: 5 September 2019; Published: 6 September 2019

\begin{abstract}
Rare diseases are a heterogeneous group of very different clinical syndromes. Their most common causes are defects in the hereditary material, and they can therefore be passed on to descendants. Rare diseases become manifest in almost all organs and often have a systemic expressivity, i.e., they affect several organs simultaneously. An effective causal therapy is often not available and can only be developed when the underlying causes of the disease are understood. In this review, we focus on Niemann-Pick disease type C1 (NPC1), which is a rare lipid-storage disorder. Lipids, in particular phospholipids, are a major component of the cell membrane and play important roles in cellular functions, such as extracellular receptor signaling, intracellular second messengers and cellular pressure regulation. An excessive storage of fats, as seen in NPC1, can cause permanent damage to cells and tissues in the brain and peripheral nervous system, but also in other parts of the body. Here, we summarize the impact of NPC1 pathology on several organ systems, as revealed in experimental animal models and humans, and give an overview of current available treatment options.
\end{abstract}

Keywords: neurodegeneration; lipid storage disorder; RT-PCR; histology; electron microscopy, cholesterol homeostasis; miglustat; cyclodextrin; treatment

\section{Introduction}

The rare Niemann-Pick disease type C1 (NPC1) is an autosomal-recessive, lipid-storage disorder characterized by neonatal jaundice, hepatosplenomegaly, and progressive neurodegeneration [1-3] The mutation responsible for approximately $95 \%$ of these cases has been mapped to a gene on chromosome 18q11 designated NPC1 [4]. The progressive neurodegeneration induces ataxia, dystonia, and impairment of intellectual function $[2,5,6]$. The NPC1 protein is involved in intracellular lipid trafficking $[7,8]$. The defect caused by mutations in the NPC1 gene induces accumulation of unesterified cholesterol, glycosphingolipids, and other fatty acids in the endosomal/lysosomal system [9]. This impaired lipid transport leads particularly to an extensive loss of Purkinje cells in the cerebellum and degeneration of other central nervous compartments [10-13]. Although all NPC1 cells show cholesterol 
and glycosphingolipid accumulation, the major clinical impact is in the liver and brain [14]. Many affected individuals have liver disease at birth. Most begin to show symptoms of neurodegeneration as young children, with learning difficulties and motor coordination problems being paramount. These individuals typically die in their teen years. There is also an infantile form of the disease; these infants show hepatosplenomegaly, fail to thrive, and die within 2-3 years. Other individuals with a milder form of the disease enjoy a normal childhood and are diagnosed as adults, with early dementia as the predominant symptom. NPC was little studied in the past because of its rarity; NPC1 is diagnosed in one in every 92,000-150,000 births, though recent genome and exome analysis including late appearing phenotypes predicts an increased incidence of one in 20,000-39,000 births [15]. However, biomedical scientists took more notice when the NPC1 gene was shown to encode a large membrane protein with features shared by several key regulators of cholesterol homeostasis. Identification of the NPC2 protein by Lobel's laboratory in 2000 [1] revealed a small soluble glycoprotein that likely partners with NPC1 in transporting lipids.

\section{Lipid Trafficking and NPC1 (Niemann-Pick Disease Type C1)}

\subsection{Cholesterol Transport}

Cholesterol homeostasis is essential for the functional integrity of the cell [3]. Nearly all cells in the body, including neurons of the central nervous system (CNS), take up cholesteryl ester and/or unesterified cholesterol carried in various lipoproteins from the surrounding pericellular fluid by receptor-mediated and bulk-phase endocytosis $[16,17]$. Both the cellular content and distribution of cholesterol within the cell are highly dynamic and tightly regulated through de novo synthesis of cholesterol by the endoplasmic reticulum (ER) [4], and by uptake of cholesterol ester-rich lipoprotein particles circulating in the serum by the low-density lipoprotein (LDL) receptor pathway [9]. The main sorting station for cholesterol within the cell is the late endosome (LE), an intermediate stage in the endosomal-lysosomal trafficking pathway. Two LE proteins, NPC1 and NPC2, appear to be key players that initiate the sorting process [18-21].

\subsection{NPC Protein Function}

\subsubsection{NPC1}

NPC1 is a large glycoprotein with 13 transmembrane-spanning domains that is found in LE [22]. It contains a five-transmembrane domain, called the 'sterol-sensing domain' that it is found in multiple other proteins hypothesized to sense the cholesterol content of their surroundings. A large hydrophilic $\mathrm{N}$-terminal domain and two hydrophilic loops extend into the endosome lumen, but functions and/or binding partners are unknown. In the steady state, most NPC1 protein is found in LE, but the protein is present in tubules and vesicles that bud off from endosomes, traffic across the cell and then return [23]. The physiological importance of the NPC1 protein is emphasized by its conservation (yeast, insects, worms, and mammals all have NPC1), although these organisms diverge considerably in their need for, and handling of, sterols.

\subsubsection{NPC2}

The NPC2 gene encodes a protein with the reassuring features of a bona fide lipid-transport protein. NPC2 is a soluble glycoprotein that is delivered to lysosomes by virtue of its mannose phosphate moiety [1]. It is also secreted and found in epididymal fluid, bile, and milk. The secreted protein was purified in apo- and sterol-bound forms [24]. Apo-NPC2 was found to have an incipient ligand-binding pocket, which expands to accommodate cholesterol (Figure 1). NPC2 was shown, in in vitro assays, to rapidly transport cholesterol from donor to acceptor membranes via a collisional mechanism [25]. As might be expected for a lysosomal protein, transfer activity was greater in an 
acidic environment and was enhanced by the presence of the late-endosome/lysosome (LE/LY) -specific lipid lysobisphosphatidic acid.

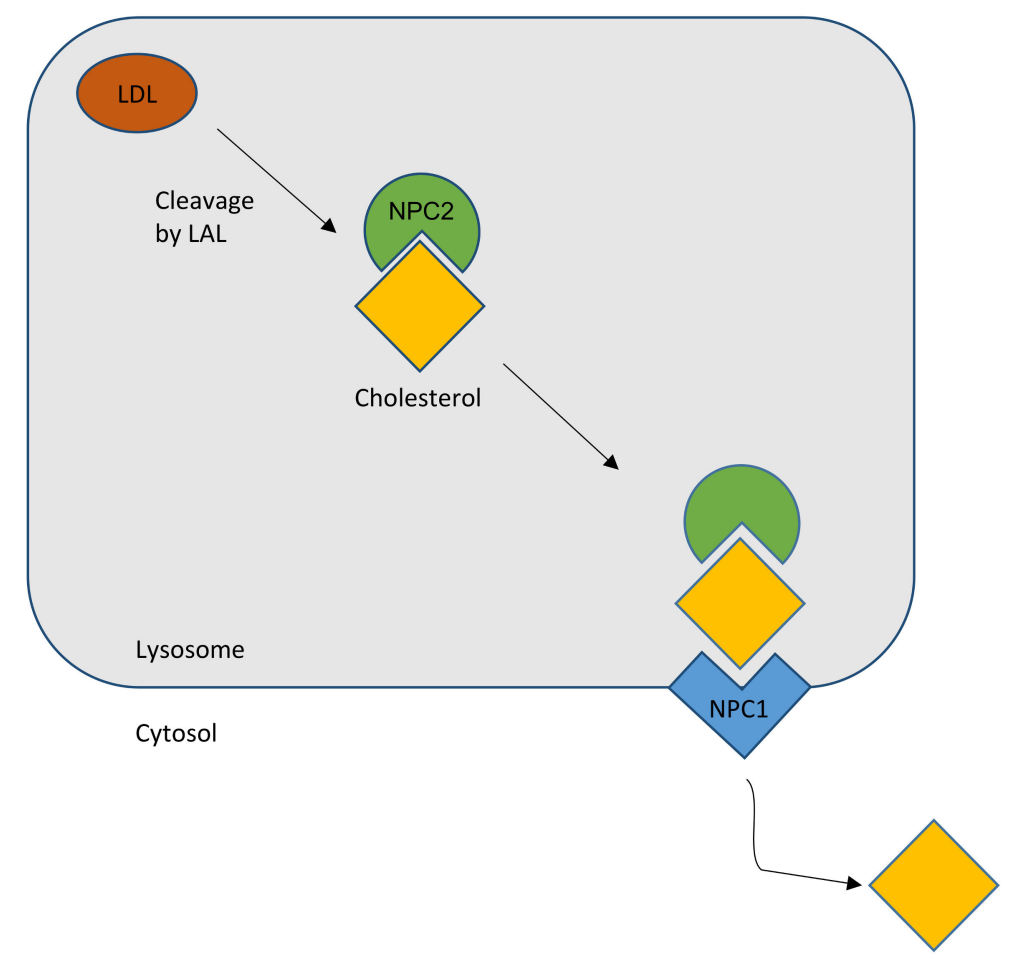

Figure 1. Schematic outline of the normal cholesterol trafficking via NPC2 and NPC1 interaction. LAL, lysosomal acid lipase (courtesy of René Thiemer, modified after [26]).

In summary, the most favored hypothesis is that, as a lipid cargo is brought to the LE/LY, the lipids are digested into their constituent molecules. NPC2 facilitates the transfer of cholesterol, and perhaps other lipids, to the delimiting membrane of the organelle. NPC1 senses the rising membrane cholesterol content and signals for the membrane to bud, carrying cargo to destinations throughout the cell (Figure 1).

\subsection{Diagnostic Tools}

The distinct heterogeneity of this disease makes it difficult to diagnose. There are several options to diagnose NPC: skin and liver biopsy for filipin staining of cultured fibroblasts; electron microscopic analysis of vacuolation or hepatocytes containing "myelin figures" (Figure 2) [27-29]; molecular genetic analysis with direct sequencing of NPC1 and NPC2 gene mutations [28]; bone marrow aspiration for the detection of foamy histiocytes [30,31]; and use of cholesterol esterification assays and oxysterol assay-based screening to measure the increase of cholestane- $3 \beta, 5 \alpha, 6 \beta$-triol (cholesterol oxidation product, "triol") [32-35]. A possible non-chemical biomarker and treatment control may consist in olfactory testing, since olfactory deficits may mirror the progress of the disease [36]. However, as yet there are no human data available [27]. 

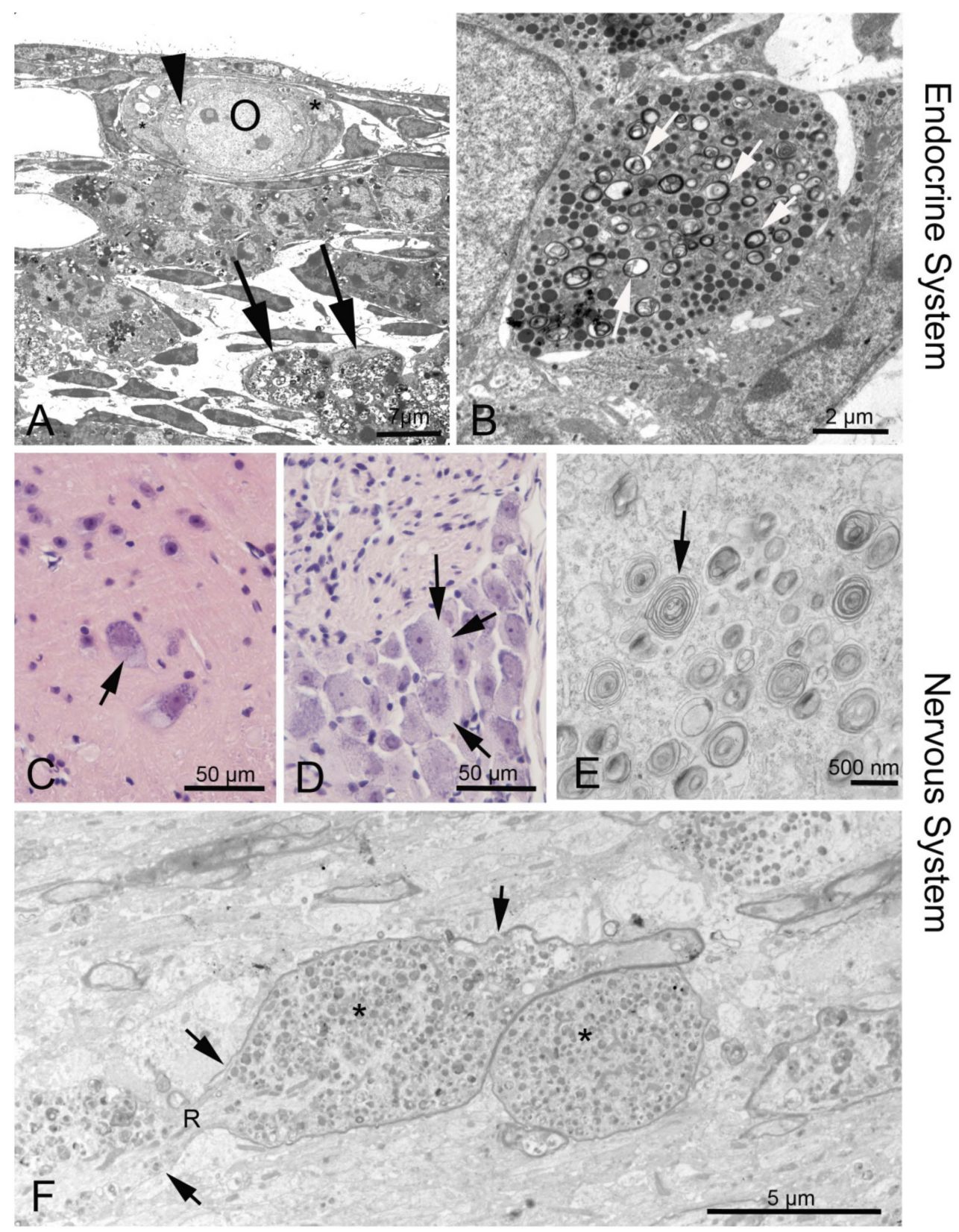

Figure 2. Phenotypes of NPC1 in the endocrine and nervous system. (A) Ovary of an $\mathrm{Npc1}^{-/-}$mouse. The oocyte $(\mathrm{O})$ contains enlarged endoplasmic reticulum (ER) with myelin-like deposits (arrowhead), as does the surrounding follicular epithelial cell (asterisk). Large accumulations are seen in a macrophage (arrows). (B) Neuroendocrine cell in the anterior pituitary. Arrows point at myelin-like inclusions between secretory vesicles. (C) Some alpha motor neurons in the anterior horn of the spinal cord are filled with light material replacing the darker perinuclear Nissl substance of the endoplasmic reticulum. (D) Similar damage is seen in dorsal root ganglion cells (arrows). (F) Corpus callosum: A longitudinal nerve fiber is enlarged and congested by autophagosome content (asterisks) that interrupts the continuity of neurofilaments and neurotubuli. The myelin sheath (arrows) has also thinned and disintegrated. R, node of Ranvier.

\subsection{Therapies}

So far, there is no causal therapy of NPC1, though the iminosugar miglustat (Zavesca ${ }^{\circledR}$ ) is the only approved drug in Europe used for supporting and symptomatic therapy in NPC1 [37]. Miglustat is a small molecule that inhibits glycosylceramid synthase, one of the key components of the 
glycosphingolipid biosynthesis, therefore reducing intracellular lipid storage [38]. Long-term therapy with miglustat has been shown to increase lifespan and stabilize neurological functions. Additionally, miglustat has been ascribed activity against oxidative stress [39]. However, limitations consist in mainly gastrointestinal side effects such as diarrhea, weight decrease, and flatulence, but also tremor [40]. A further promising drug, 2-hydroxypropyl- $\beta$-cyclodextrin (HP $\beta C D)$ - a cyclic oligosaccharide-is used as an enabling excipient in pharmaceutical formulations, as well as a cholesterol modifier in vivo. Therapy results in delayed onset of neurological symptoms with increased lifespan [37,38,41]. Matsuo et al. [42] reported in a clinical trial that $H P \beta C D$ was effective in NPC1 patients, suggesting that $H P \beta C D$ is a promising drug candidate in NPC1 disease. HP $\beta C D$ overcomes the transport defect leading to excretion of accumulated cholesterol as bile acid, as shown in $\mathrm{Npc1}^{-/}$mice [43]. It has been suggested that cholesterol efflux is mediated by the ATP binding cassette subfamily G member 1 (ABCG1), which promotes biliary excretion of sterols, ameliorating liver function $[43,44]$. Unfortunately, HP $\beta C D$ administration also has side effects, particularly on the survival of outer hair cells, leading to hearing loss. This major side effect occurs in a dose- and duration-dependent manner [45,46]. What is more, in an open-label, dose-escalation phase 1-2a study, promising effects of HP $\beta C D$ were recorded [47]; however, preliminary results of a current multinational phase $2 \mathrm{~b} / 3$ clinical study involving about 50 patients treated with $200 \mathrm{mg} / \mathrm{kg}$ intrathecally applied HP $\beta C D$ every 2 weeks indicate doubts that $\mathrm{HP} \beta C D$ achieves benefits when compared to a placebo [48-50].

Another promising therapy, so far applied only in animal models, consists of a combination of miglustat, the neurosteroid allopregnanolone, and $\operatorname{HP} \beta C D$ [13,51-53], resulting in further prevention of cerebellar Purkinje cell loss, improved motor function, reduced intracellular lipid storage, and prolonged life span in $\mathrm{NpC1}^{-/-}$mice.

Another therapeutic approach showed that the activity of the liver $X$ receptor $\beta$ (LXR $\beta$ ) can regulate the cholesterol flux from the brain, which leads to a reduction of neuroinflammation and slows therefore the neurodegeneration process. However, these positive effects result only in a modest lifespan prolongation $[54,55]$. Nevertheless, LXR $\beta$ activation by treatment with an LXR agonist (T1317) can be useful in combination, e. g., with $\mathrm{HP} \beta C D$.

In the absence of a causal treatment, there is still, a need to identify novel treatment strategies. Currently, histone deacetylase inhibitors (HDACi) are a focus of interest, due to the findings that they can reduce cholesterol accumulation in LE/LY [55-58]. These enzymes mediate posttranslational deacetylation of many types of proteins, e.g., histones, transcription factors, and chaperones [59]. In spite of its interaction with many different proteins and signaling pathways, it has been shown that HDACi increases expression of the low-activity mutant NPC1 protein [56,57], at least in vitro.

A further treatment option is FTY720 (fingolimod), a sphingosin analog. This drug is already approved for human use to treat multiple sclerosis [60]. FTY720 can enter the cell nucleus, where it is phosphorylated by sphingosine kinase 2 (SphK2). This active form is an inhibitor of class I histone deacetylases. The advantage of this drug over available HDACi is to regulate the expression of only a limited number of genes, which are restricted to cholesterol and sphingolipid metabolism, compared with the large number (thousands of genes [61]), which are activated by HDACi [60].

Another treatment approach is the application of arimoclomol, a coinducer of heat shock protein 70 (HSP 70) that improves the binding of several sphingolipid-degrading enzymes to their essential cofactor bis(monoacyl)glycerophosphate in vitro [62,63]. Beneficial effects for NPC patients have also been observed with drugs such as ursodeoxycholic acid [64,65] and acetyl-DL-leucine [66].

Moreover, an increased level of functional NPC1 can be achieved using gene therapy [67]. In some studies, it has been shown that the adeno-associated virus (AAV) 9 vector may successfully transfer the NPC1 gene into the CNS of $\mathrm{NpC}^{-/-}$mice [67-69]. Systemic delivery of a functional NPC1 gene into $\mathrm{Npc1}^{-/-}$mice significantly extends the lifespan, ameliorates neurodegeneration, and improves behavioral abnormalities [67-69]. The current state of this research is promising. 


\section{Pathology of NPC1 in Humans and Mice}

In the following, we give a systematic overview of NPC1 pathology in various, mostly peripheral, tissues and organs. We also compile our own behavioral and novel histopathological material using the Jackson mouse strain BALB/cNctr-Npc1 ${ }^{\mathrm{m} 1 \mathrm{~N} /-} \mathrm{J}$ (see Supplementary Materials).

\subsection{Behavior}

A combined therapy using $\mathrm{HP} \beta C D$, allopregnanolone, and miglustat has been shown to delay disease onset and increase the lifespan of $\mathrm{Npc1}$ mutant mice by reducing intraneuronal lipid storage [51]. Encouraged by these findings, the effects of therapeutic drugs on the behavior of $\mathrm{Npc1}^{-/-}$mice (BALB/CJ $\mathrm{NPC1NIH)} \mathrm{were} \mathrm{evaluated} \mathrm{in} \mathrm{several} \mathrm{studies.} \mathrm{The} \mathrm{effects} \mathrm{of} \mathrm{HP} \beta \mathrm{CD} /$ allopregnanolone/miglustat combination therapy on motor and cognitive performance of $\mathrm{Npc1}$ mutant mice was first explored using standard behavioral tests [53]. Combination-treatment of mutant mice significantly and positively influenced motor dysfunction in an open field and elevated plus maze and accelerod tests when compared to sham-treated mutant mice. Spatial learning in the Morris water maze, however, did not benefit from therapy [53].

A follow-up study addressed the question of possible side effects of therapeutic drugs [70]. For this purpose, a battery of standard behavioral tests was used on healthy, wild-type mice to study pharmacological effects of miglustat as a monotherapy, in comparison to the well-known combination therapy [51,53]. Combination treatment caused reduced brain and body weights, whereas miglustat alone led to reduced brain weight but unaltered body weight. Motor capabilities and spontaneous motor behavior were unaltered in both drug-treated groups. However, miglustat-treated mice displayed impaired spatial learning compared to sham- and combination-treated wild-type mice. Both combination- and miglustat-treated mice showed enhanced anxiety in the elevated plus maze compared to sham-treated mice. The authors suggested that $\mathrm{HP} \beta \mathrm{CD} /$ allopregnanolone ameliorates most side effects of miglustat in wild-type mice [70]. However, further behavioral studies are needed to investigate the effects of each drug separately.

Another therapy strategy used miglustat in combination with the calcium modulator curcumin and the anti-inflammatory drug ibuprofen in $\mathrm{Npc}^{-/-}$mice [71]. Motor function and coordination was evaluated by measuring rearing ability in an open-field test. The positive effect of miglustat monotherapy was further improved by additional dual therapy with curcumin and miglustat, and the triple combination therapy [71]. However, the authors have not performed behavioral tests for cognition and anxiety.

\subsection{Sensory Systems}

\subsubsection{Hearing}

In contrast to general neurological deficits, sensory systems in NPC1 have attracted only minor diagnostic and research attention. Only a few studies refer to auditory phenotypes in NPC1 in patients [72] and in mice [73], although the most important approach to the auditory system came with the observation that $\mathrm{HP} \beta C D$ as an effective treatment agent (see above) can lead to severe hearing loss $[45,52,74]$. Outer hair cells seem to be the most susceptible targets of CD [45,75], but the reasons for the ototoxicity are currently not clear [52]. Pathological brainstem recordings also indicate auditory pathway involvement in NPC1 patients [76].

\subsubsection{Vision}

Visual deficits were first published by Claudepierre et al. [77] in Npc1 mutant mice and showed that lack of Npc1 leads to pathological electroretinogram responses, retinal degeneration with disruption of the retinal pigment epithelium, and degeneration of bipolar and optic ganglion cells. NPC1-typical autophagosomes were also found in glia and nerve fibers along the optic nerve in mutant mice [78]. Functionally, Npc1 pathology in mice leads to degenerated visual pathways, as revealed by analyzing 
visual evoked potentials [79]. ERG recordings of NPC1 patients have not yet been performed, but saccadic eye movements have been often observed in adult patients, reflecting general neurological deficits at the levels of frontal eye fields and the brainstem [80], but there are no reports on retinal changes in patients who underwent treatment.

\subsubsection{Olfaction}

As observed in several other neurodegenerative disorders, the Npc1 mutation also elicits olfactory deficits, at least in experimental animals [81]. Peripheral olfactory receptor neurons and associated supporting glia are severely damaged, leading to hyposmia in $\mathrm{Npc1}^{-/-}$mice [81], which goes along with reduced electrophysiological responses in the olfactory mucosa of older animals [81]. Considerable damage to olfactory receptor cells is accompanied by a downregulation of certain, but not all, olfactory receptors [36], and is accompanied by severe central astro- and microgliosis of the olfactory bulb [81,82]. Due to the extraordinary plasticity of the olfactory system, regenerative proliferation activities have been observed both in the olfactory mucosa [83] and at the CNS level [36,82]. All these effects could be prevented by treatments with $\mathrm{HP} \beta C D$ (see above). Olfactory performance in humans has not yet been investigated.

\subsubsection{Peripheral Nervous System}

As most tissues are affected in NPC1, and especially CNS disorders play a crucial role (Figure 2E), it should not be surprising that peripheral nerves are also involved. However, there are few systematic reports on the peripheral nervous system, and no documentation on treatment. Bagel et al. [84] report myelination defects of Schwann cells, rather than axonal damage, in cats. Electrophysiological studies showed altered lower-limb somatosensory evoked potentials in adult patients [76].

Our group noted neuronal cell degeneration in dorsal root ganglia (Figure 2C,D) as well as in satellite cells of the trigeminal nerve, and also described deposits within trigeminal ganglion cells in $\mathrm{Npc1}^{-/-}$mice. Similar results were obtained earlier in the acid sphingomyelinase knock-out (ASMKO) mouse model of Niemann-Pick disease type A [85].

\subsection{Endocrine Organs and Reproductive System}

Endocrine disorders are not the focus of research on human NPC1 mutations, and the few available data refer mostly to $\mathrm{Npc1}$ mouse models. Female $\mathrm{Npc1}^{-/}$mice are infertile, probably by failure of the hypothalamic control of the pituitary [86]. Gévry et al. described hypoplastic pituitaries with prolactin expression. Failing ovulation and missing corpora lutea in the $\mathrm{Npcl}^{-/-}$mutant mouse could be overcome with gonadotropin treatment [87]. Our electron microscopic studies demonstrate discrete myelin-like deposits in diverse hormone-producing cells of the anterior pituitary and similar inclusions in follicular epithelial cells of the ovary (Figure 2A,B). Accordingly, cholesterol balance is also disturbed in male $\mathrm{Npc1}^{-/-}$mice [88], leading to sperm defects and altered testosterone production $[89,90]$.

In the adrenal gland, Elleder and Smid [91] observed only mild morphological changes, mainly in stromal cells, but barely in the cortex, and not at all in the medulla. This is confirmed by our own histological studies in $\mathrm{Npc1}^{-/-}$mice (not shown).

\subsection{Gastrointestinal Tract (GI)}

The GI tract has been focused as the "visceral type" of NPC1, especially the largest associated gland, the liver. Apart from the lipogenetic potential of the liver, we observed a plethora of cell types and tissues in the GI tract that contain NPC1-typical deposits, e.g., epithelial cells of the duodenal mucosa (Figure 3B,C) and the gallbladder (Figure 3F), as well as within the ganglionic plexuses (Figure 3A,D,E). This may be associated with the delayed intestinal transit [92]. In the same $\mathrm{Npc1}^{-/}$mouse model, Cougnoux et al. [93] observed significant increases in cyanobacteria and epsilon-proteobacteria, as well as macrophage dysfunction, within the GI tract. Additionally, a high frequency of Crohn's disease 
has been observed in NPC1 patients [94-96], though the pathomechanisms of Crohn's disease in NPC1 are different with regard to microbiota changes, at least in the widely used $N p c 1$ mouse model [93].

\subsection{Pancreas}

The NPC1 condition does not seem to produce clinically important effects in both endocrine and exocrine pancreas; there is only one report on morphological changes in acinar cells in NPC [97]. We observed only some myelin-like inclusions in pancreatic acinar cells, but no major structural damage (Figure 3G).
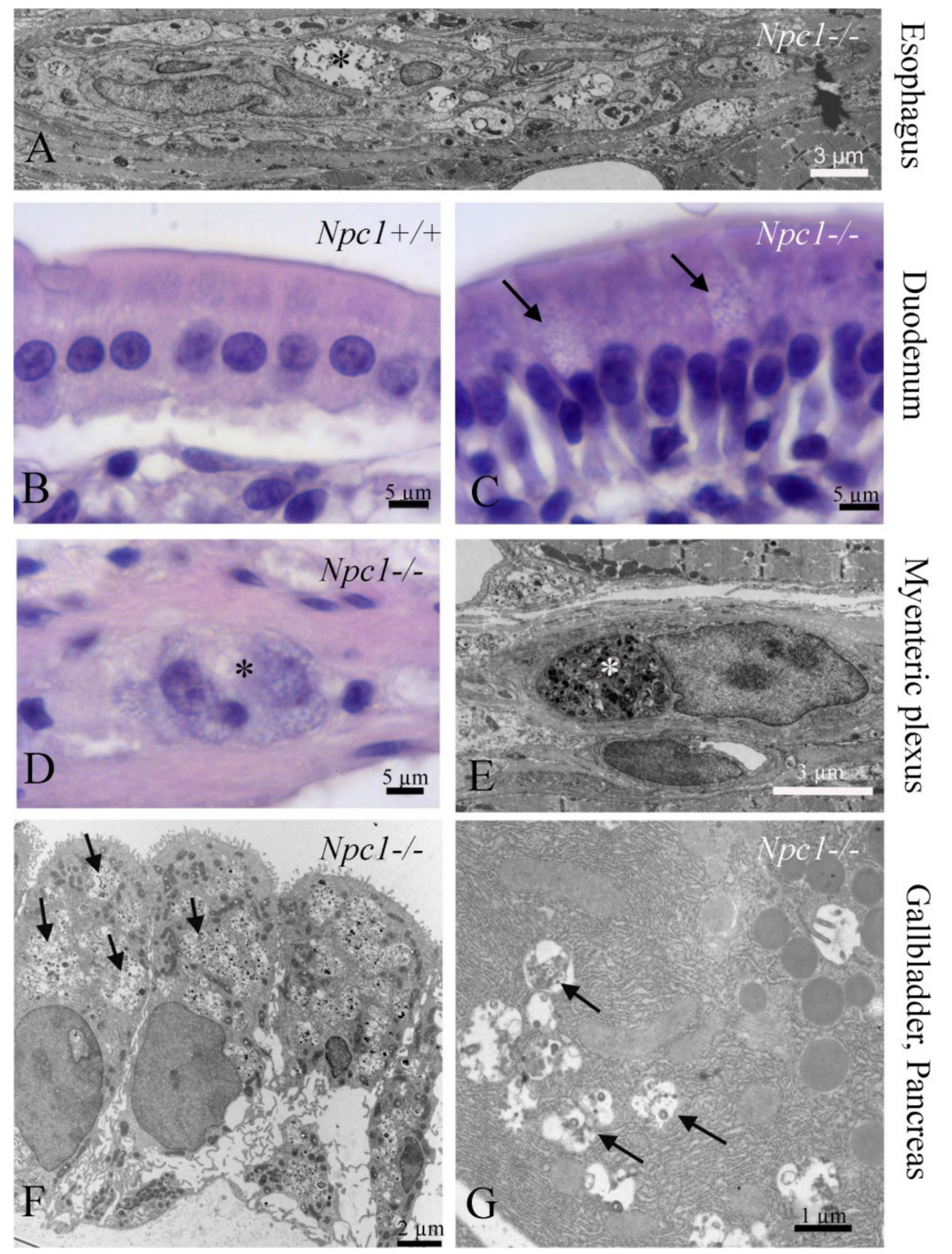

Figure 3. Phenotypes of NPC1 in the gastrointestinal tract. (A) Myenteric plexus in the esophagus with myelin-like inclusions in glia cells (asterisk). (B) Normal duodenal enterocytes in $\mathrm{Npc1}^{+/+}$, and (C) pathological cells (arrows) in an $\mathrm{Npc}^{-/-}$mouse. (D,E) Autophagosomes in ganglion cells of the myenteric plexus in the duodenum. (F) LE/LY storage in epithelium of the gallbladder and (G), in acinar cells of the exocrine pancreas.

\subsection{Lung}

Although NPC1 affects almost all tissues, pulmonary dysfunction has rarely been shown in NPC1 patients compared to NPC2. It is, however, more common in NPC1 patients than previously 
known [98]. Recently, Roszell et al. [99] found severe pathological structural alterations in all cell types of the blood-air barrier in NPC1 mouse and cat models, and mainly altered surfactant-producing type II cells, elevated levels of phospholipids in the alveolar space, larger and more numerous macrophages, and thickening of the alveolar septum. In the Npc ${ }^{\text {nmf164 }}$ model, Erickson et al. [100] found even aggravated pulmonary pathology after nasal inhalation of $\mathrm{HP} \beta C D$. Histological features of murine NPC1-caused lung disease are shown in Figure 4A-C. Many patients suffer from incurable bacterial or viral bronchopulmonary infections that are exacerbated by NPC1-predamaged pulmonary tissue [101].

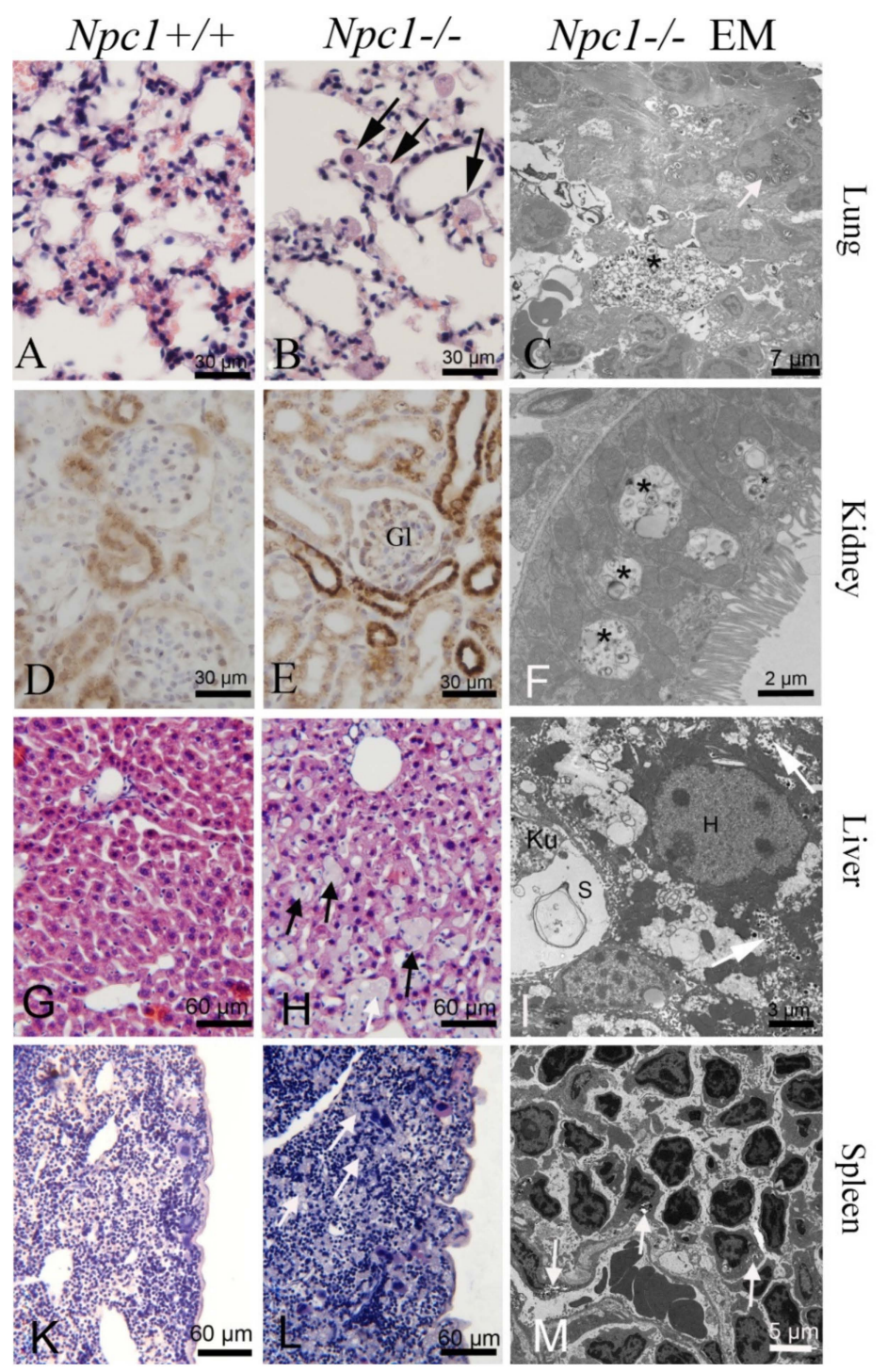

Figure 4. Phenotypes of NPC1 in visceral organs. Left column $(\mathbf{A}, \mathbf{D}, \mathrm{G}, \mathbf{K})$ : wildtype control animals $\left(\mathrm{Npcl}^{+/+}\right)$, middle column: mutant mice $\left(\mathrm{Npc1}^{-/-}\right)$, right column: mutant animals at the electron microscopic level. The lung presents alveolar edema and emphysema (B) and many activated pulmonary macrophages (foam cells, arrows). (C) Detailed view of a macrophage filled up with autophagosomes (asterisk) and a normal alveolar cell type II (arrow). In the kidney, cathepsin D immunoreactivity shows increased lysosomal activity in $\mathrm{Npc}^{-/-}$mice (D), especially in proximal tubules and endothelial cells, as well as podocytes of the glomerulus (E, Gl). (F) Myelin-like deposits (asterisks) in proximal tubular cells. In the liver, numerous pale cells are also visible ( $\mathbf{H}$, arrows). (I) Kupffer cells (Ku) in the sinusoids (S) and hepatocytes $(\mathrm{H})$ are filled with autophagosomes (arrows). (L) In the spleen, numerous foam cells are seen (arrows). (M) Inclusions in endothelial cells and macrophages (arrows). 


\subsection{Kidney}

In Npc1 mutant mice, cholesterol deposits are increased in the kidney [43]. Lipid inclusions are observed in all parts of the tubular system, especially the proximal tubules, but also podocytes and endothelium in the glomeruli are affected (Figure 4D-F). Similar observations have been reported only in a related mouse model mimicking human NPC type A [102]. The kidney, however, plays an important part during therapy with $\mathrm{HP} \beta C D$, as this agent is completely cleared from the plasma by the kidney $[43,103]$.

\subsection{Liver and Biliary Tract}

Liver plays the key role in the clearance of circulating cholesterol carried in lipoproteins. In both human and mouse with a mutation in NPC1, the liver represents the highest rate of sterol accumulation, which forms a basis for the development of liver disease. Aside from hepatomegaly, Niemann-Pick patients often suffer from prolonged neonatal jaundice and ascites, as well as liver failure [104107]. Furthermore, it is known that the NPC1 mutation is the second-most common cause of neonatal cholestasis [108], whereby $10 \%$ of these patients die due to liver failure [29]. Accordingly, livers of $\mathrm{NpC1}^{-/-}$mutant mice reveal enhanced liver-tissue damage and inflammation indicated by raised hepatic apoptosis, as well as necrosis and infiltration of foamy macrophages and increased proliferation of hepatic stellate cells, resulting in liver fibrosis (Figure 4G-I) [44,109-111]. Moreover, the biliary tract is of some importance in $\mathrm{Npc1}^{-/-}$, since bile acid metabolites such as plasma oxysterols, cholestan-3 $\beta, 5 \alpha, 6 \beta$-triol (Triol), and 7-ketocholesterol (7-KC) play an increasing role as biomarkers for NPC1.

The cause for all these pathological hallmarks is, beside the NPC1 mutation-associated cholesterol accumulation, the concomitant dysregulation of hepatic lipid metabolism. Cholesterol homeostasis is characterized by a balance of lipogenesis and lipolysis. Lipogenesis is mainly regulated by the nuclear receptor liver $\mathrm{X}$ receptor (lxr) and its target genes, including, among others, sterol regulatory element-binding transcription factor 1c (srebp1c), which is known to be upregulated in livers of $\mathrm{Npc1}^{-/-}$ mutant mice [43]. Beside the sterol regulatory element binding protein (SREBP) pathway [112], the peroxisome proliferator-activated receptor (PPAR) pathway with the genes peroxisomal acyl-coenzyme A oxidase 1 (acox1) and fatty acid transport protein 2 (fatp2) is implicated in the regulation of free fatty acid hepatic metabolism, which was found downregulated in $\mathrm{Npc}^{-/}$mutant mice [44]. Moreover, the peroxisome proliferator-activated receptor $\alpha$ (ppar $\alpha)$ regulates the expression of liver genes involved in mitochondrial and/or peroxisomal fatty acid $\beta$-oxidation, meaning an enhanced lipolysis. In several studies, it was reported that ppar $\alpha$ gene expression is decreased in livers of $\mathrm{Npc1}^{-/}$mutant mice $[44,112]$. Therefore, decreased expression of the ppar $\alpha$ gene provides an additional plausible explanation for the accumulation of free fatty acids in NPC1 disease. Target downregulated genes of ppar $\alpha$ in $\mathrm{NpC1}^{-/-}$mutant mice are apolipoprotein E (apoE) and ATP-binding cassette A1 (abca1) [44], which are involved in transporting cholesterol to the plasma membrane [113]. In summary, the observed shift of the lipid metabolism towards lipogenesis with simultaneously reduced lipolysis most probably supports hepatic steatosis and underlines the pathological relevance of nuclear receptors in both human and mouse with an Npc1 mutation. The histological phenotype of NPC1-affected liver tissue is displayed in Figure 1G-I. Therapeutic approaches showed that both the combination therapy and HP $\beta C D$ monotherapy ameliorate NPC1 liver disease symptoms by causing a reduction of hepatic lipids. In this context, the therapeutic effect is related to ppar $\alpha$ - and acox1-associated lipolysis/ $\beta$-oxidation and to fatp2-induced fatty acid transport $[31,32,114]$.

\subsection{Spleen and Lymphatic System}

Data on a disturbed balance within splenocyte subpopulations in humans is currently not available. As a matter of fact, irregular consequences of NPC1 malfunction with regard to the immune system have not yet been described in NPC1, in contrast to other storage diseases. For example, 
increased autoantibody formation has been found in Gaucher and Fabry's disease (reviewed by [115]). The histological features of $\mathrm{Npc1}^{-/-}$affected mouse spleen is shown in Figure 4K-M. There is apparent infiltration with spleen macrophages (foam cells). A recent fluorescence activated cell sorting (FACS) analysis revealed that increased numbers of splenic myeloid cells in $\mathrm{Npc1}^{-/-}$mice were normalized by a combination treatment with miglustat and HP $\beta C D$. Treated $\mathrm{Npc1}^{--}$mice also showed decreased numbers of cytotoxic $\mathrm{T}$ cells and increased numbers of $\mathrm{T}$ helper cells [116].

\subsection{Cardiovascular System}

It is well known that the formation of foam cells or atherosclerotic plaque is the hallmark event leading to coronary heart disease $[117,118]$. The endothelium in many organ systems in NPC1 is typically so affected (Figure 5), and cholesterol imbalance may lead to clinically adverse situations such as arteriosclerosis. Foam cells in atherosclerotic lesions derive from macrophages and vascular smooth muscle cells [119]. Recent reports have shown that atherogenesis may be prevented by HP $\beta C D$ [120-122]. Interestingly, cardiac muscle and associated tissues are almost free of NPC1-related pathology (Figure 5) and do not as yet play a major role in diagnostic and therapeutic considerations of NPC1.

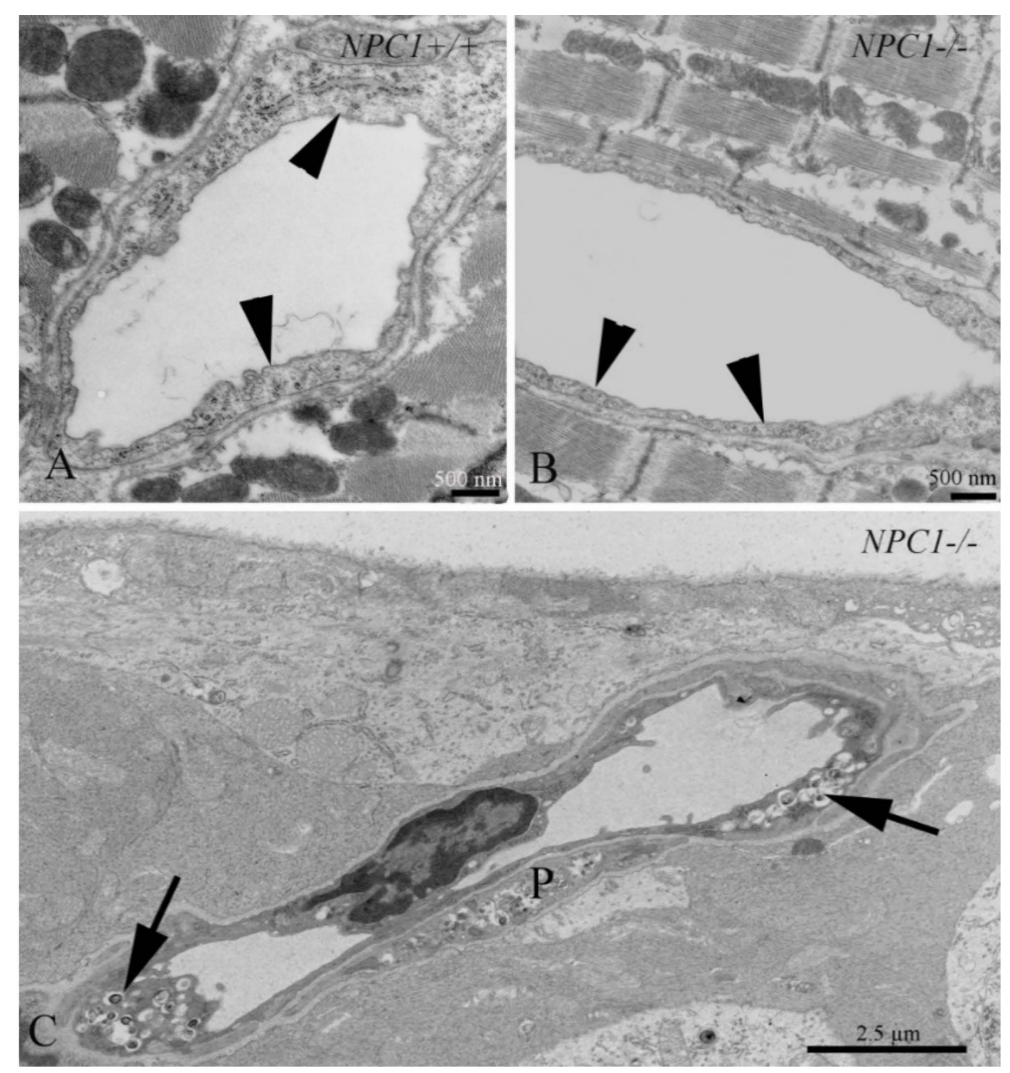

Figure 5. Phenotypes of NPC1 in the cardiovascular system. (A) Cardiac muscle with an endothelial cell (arrowheads) in an $\mathrm{Npc1}^{+/+}$(control) mouse. (B) Endothelial cells, in contrast to most other organs, do not contain lipid-like inclusions. (C) Capillary (arrows) and a pericyte $(\mathrm{P})$ in the ganglion cell layer of the retina, are filled with NPC1-typical autophagosomes.

\subsection{Tooth}

Caries risk and activity can be a problem in patients, not only with NPC, but also with other neurological or psychiatric diseases, particularly affecting children. Disabled children often do not chew and the daily oral hygiene activities are reduced [123]. 


\section{Perspectives}

Until now, over 6000 rare diseases have been characterized by a broad diversity of disorders and symptoms that vary not only from disease to disease, but also from patient to patient suffering from the same disease. There is a strong need to develop novel treatments and understanding of how the therapies work. From lipid-storage diseases, such as NPC1, we can learn more about the cellular and molecular mechanisms underlying neurodegeneration. We should, therefore, give these rare diseases more attention.

Supplementary Materials: Supplementary materials can be found at http://www.mdpi.com/1422-0067/20/18/4392/s1. Author Contributions: All authors contributed to the conception of the manuscript; A.U.B. and M.W. wrote the manuscript.

Funding: This research was funded by Impuls Forschung, Verbund Norddeutscher Universitäten (A.U.B. and M.W.) and the Deutsche Forschungsgemeinschaft to M.W. (INST 264195-1FUGG).

Acknowledgments: The authors are indebted to Frauke Winzer for expert histology and Anja Meyer for skillful electron microscopic work. We also thank Susann Lehmann and Mathias Lietz for animal care.

Conflicts of Interest: The authors declare no conflict of interest.

\section{Abbreviations}

\begin{tabular}{|c|c|}
\hline AAV & adeno-associated virus \\
\hline $\mathrm{ABC}$ & ATP binding cassette \\
\hline ACMKO & acid sphingomyelinase knock-out \\
\hline acox1 & acyl-coenzyme A oxidase 1 \\
\hline apoE & apolipoprotein E \\
\hline ASMKO & acid sphingomyelinase knock-out \\
\hline CNS & central nervous system \\
\hline ER & endoplasmic reticulum \\
\hline FACS & fluorescence activated cell sorting \\
\hline fatp2 & fatty acid transport protein 2 \\
\hline GI & gastrointestinal \\
\hline HDACi & histone deacetylase inhibitors \\
\hline $\mathrm{HP} \beta \mathrm{CD}$ & 2-hydroxypropyl- $\beta$-cyclodextrin \\
\hline LDL & low-density lipoprotein \\
\hline $\mathrm{LE} / \mathrm{LY}$ & late endosome/lysosome \\
\hline lxr & liver $\mathrm{X}$ receptor \\
\hline NPC1 & Niemann-Pick disease type $\mathrm{C} 1$ \\
\hline PPAR & peroxisome proliferator-activated receptor \\
\hline SphK2 & sphingosine kinase 2 \\
\hline SREBP & sterol regulatory element binding protein \\
\hline
\end{tabular}

\section{References}

1. Naureckiene, S.; Sleat, D.E.; Lackland, H.; Fensom, A.; Vanier, M.T.; Wattiaux, R.; Jadot, M.; Lobel, P. Identification of HE1 as the second gene of Niemann-Pick C disease. Science 2000, 290, 2298-2301. [CrossRef]

2. Garver, W.S.; Francis, G.A.; Jelinek, D.; Shepherd, G.; Flynn, J.; Castro, G.; Walsh Vockley, C.; Coppock, D.L.; Pettit, K.M.; Heidenreich, R.A.; et al. The national Niemann-Pick C1 disease database: report of clinical features and health problems. Am. J. Med. Genet. A 2007, 143, 1204-1211. [CrossRef]

3. Garver, W.S.; Jelinek, D.; Oyarzo, J.N.; Flynn, J.; Zuckerman, M.; Krishnan, K.; Chung, B.H.; Heidenreich, R.A. Characterization of liver disease and lipid metabolism in the Niemann-Pick C1 mouse. J. Cell. Biochem. 2007, 101, 498-516. [CrossRef]

4. Garver, W.S.; Jelinek, D.; Meaney, F.J.; Flynn, J.; Pettit, K.M.; Shepherd, G.; Heidenreich, R.A.; Vockley, C.M.; Castro, G.; Francis, G.A. The national Niemann-Pick Type $\mathrm{C} 1$ disease database: correlation of lipid profiles, mutations, and biochemical phenotypes. J. Lipid Res. 2010, 51, 406-415. [CrossRef]

5. Vanier, M.T.; Millat, G. Niemann-Pick disease type C. Clin. Genet. 2003, 64, 269-281. [CrossRef] 
6. Spiegel, R.; Raas-Rothschild, A.; Reish, O.; Regev, M.; Meiner, V.; Bargal, R.; Sury, V.; Meir, K.; Nadjari, M.; Hermann, G.; et al. The clinical spectrum of fetal Niemann-Pick type C. Am. J. Med. Genet. A 2009, 149, 446-450. [CrossRef]

7. Yu, X.H.; Jiang, N.; Yao, P.B.; Zheng, X.L.; Cayabyab, F.S.; Tang, C.K. NPC1, intracellular cholesterol trafficking and atherosclerosis. Clin. Chim. Acta. 2014, 429, 69-75. [CrossRef]

8. Chu, B.B.; Liao, Y.C.; Qi, W.; Xie, C.; Du, X.; Wang, J.; Yang, H.; Miao, H.H.; Li, B.L.; Song, B.L. Cholesterol transport through lysosome-peroxisome membrane contacts. Cell 2015, 161, 291-306. [CrossRef]

9. Carstea, E.D.; Morris, J.A.; Coleman, K.G.; Loftus, S.K.; Zhang, D.; Cummings, C.; Gu, J.; Rosenfeld, M.A.; Pavan, W.J.; Krizman, D.B.; et al. Niemann-Pick C1 disease gene: homology to mediators of cholesterol homeostasis. Science 1997, 277, 228-231. [CrossRef]

10. Elleder, M.; Jirasek, A.; Smid, F.; Ledvinova, J.; Besley, G.T. Niemann-Pick disease type C. study on the nature of the cerebral storage process. Acta. Neuropathol. 1985, 66, 325-336. [CrossRef]

11. Tanaka, J.; Nakamura, H.; Miyawaki, S. Cerebellar involvement in murine sphingomyelinosis: a new model of Niemann-Pick disease. J. Neuropathol. Exp. Neurol. 1988, 47, 291-300. [CrossRef]

12. Sarna, J.R.; Larouche, M.; Marzban, H.; Sillitoe, R.V.; Rancourt, D.E.; Hawkes, R. Patterned purkinje cell degeneration in mouse models of Niemann-Pick type C disease. J. Comp. Neurol. 2003, 456, $279-291$. [CrossRef]

13. Maass, F.; Petersen, J.; Hovakimyan, M.; Schmitt, O.; Witt, M.; Hawlitschka, A.; Lukas, J.; Rolfs, A.; Wree, A. Reduced cerebellar neurodegeneration after combined therapy with cyclodextrin/allopregnanolone and miglustat in NPC1: A mouse model of Niemann-Pick type C1 disease. J. Neurosci. Res. 2015, 93, 433-442. [CrossRef]

14. Liscum, L. A role for NPC1 and NPC2 in intestinal cholesterol absorption-the hypothesis gutted. Biochem. J. 2007, 408, e1-e3. [CrossRef]

15. Wassif, C.A.; Cross, J.L.; Iben, J.; Sanchez-Pulido, L.; Cougnoux, A.; Platt, F.M.; Ory, D.S.; Ponting, C.P.; Bailey-Wilson, J.E.; Biesecker, L.G.; et al. High incidence of unrecognized visceral/neurological late-onset Niemann-Pick disease, type C1, predicted by analysis of massively parallel sequencing data sets. Genet. Med. 2016, 18, 41-48. [CrossRef]

16. Brown, M.S.; Goldstein, J.L. A receptor-mediated pathway for cholesterol homeostasis. Science 1986, 232, 34-47. [CrossRef]

17. Liu, B.; Xie, C.; Richardson, J.A.; Turley, S.D.; Dietschy, J.M. Receptor-mediated and bulk-phase endocytosis cause macrophage and cholesterol accumulation in Niemann-Pick C disease. J. Lipid Res. 2007, 48, 1710-1723. [CrossRef]

18. Maxfield, F.R.; Menon, A.K. Intracellular sterol transport and distribution. Curr. Opin. Cell. Biol. 2006, 18, 379-385. [CrossRef]

19. Chang, T.Y.; Chang, C.C.; Ohgami, N.; Yamauchi, Y. Cholesterol sensing, trafficking, and esterification. Annu. Rev. Cell. Dev. Biol. 2006, 22, 129-157. [CrossRef]

20. Vance, J.E. Lipid imbalance in the neurological disorder, Niemann-Pick C disease. FEBS Lett. 2006, 580, 5518-5524. [CrossRef]

21. Yu, L. The structure and function of Niemann-Pick C1-like 1 protein. Curr. Opin. Lipidol. 2008, 19, $263-269$. [CrossRef]

22. Scott, C.; Ioannou, Y.A. The NPC1 protein: structure implies function. Biochim. Biophys. Acta. 2004, 1685, 8-13. [CrossRef]

23. Liscum, L.; Sturley, S.L. Intracellular trafficking of Niemann-Pick C proteins 1 and 2: obligate components of subcellular lipid transport. Biochim. Biophys. Acta. 2004, 1685, 22-27. [CrossRef]

24. Xu, S.; Benoff, B.; Liou, H.L.; Lobel, P.; Stock, A.M. Structural basis of sterol binding by NPC2, a lysosomal protein deficient in Niemann-Pick type C2 disease. J. Biol. Chem. 2007, 282, 23525-23531. [CrossRef]

25. Cheruku, S.R.; Xu, Z.; Dutia, R.; Lobel, P.; Storch, J. Mechanism of cholesterol transfer from the Niemann-Pick type C2 protein to model membranes supports a role in lysosomal cholesterol transport. J. Biol. Chem. 2006, 281, 31594-31604. [CrossRef]

26. Peake, K.B.; Vance, J.E. Defective cholesterol trafficking in Niemann-Pick C-deficient cells. FEBS Lett. 2010, 584, 2731-2739. [CrossRef]

27. Reddy, J.V.; Ganley, I.G.; Pfeffer, S.R. Clues to neuro-degeneration in Niemann-Pick type C disease from global gene expression profiling. PLoS ONE 2006, 1, e19. [CrossRef] 
28. Abe, K.; Sakai, N. Patient with Niemann-Pick disease type C: over 20 years' follow-up. BMJ Case Rep. 2017, 2017. [CrossRef]

29. Kelly, D.A.; Portmann, B.; Mowat, A.P.; Sherlock, S.; Lake, B.D. Niemann-Pick disease type C: diagnosis and outcome in children, with particular reference to liver disease. J. Pediatr. 1993, 123, 242-247. [CrossRef]

30. Gumus, E.; Haliloglu, G.; Karhan, A.N.; Demir, H.; Gurakan, F.; Topcu, M.; Yuce, A. Niemann-Pick disease type $C$ in the newborn period: a single-center experience. Eur. J. Pediatr. 2017, 176, 1669-1676. [CrossRef]

31. Rodrigues, A.F.; Gray, R.G.; Preece, M.A.; Brown, R.; Hill, F.G.; Baumann, U.; McKiernan, P.J. The usefulness of bone marrow aspiration in the diagnosis of Niemann-Pick disease type $\mathrm{C}$ in infantile liver disease. Arch. Dis. Child. 2006, 91, 841-844. [CrossRef]

32. Porter, F.D.; Scherrer, D.E.; Lanier, M.H.; Langmade, S.J.; Molugu, V.; Gale, S.E.; Olzeski, D.; Sidhu, R.; Dietzen, D.J.; Fu, R.; et al. Cholesterol oxidation products are sensitive and specific blood-based biomarkers for Niemann-Pick C1 disease. Sci. Transl. Med. 2010, 2, 56ra81. [CrossRef]

33. McKay Bounford, K.; Gissen, P. Genetic and laboratory diagnostic approach in Niemann Pick disease type C. J. Neurol. 2014, 261, S569-S575. [CrossRef]

34. Jiang, X.; Ory, D.S. Towards a new diagnostic standard for Niemann-Pick C disease. EBioMedicine 2016, 4, 18-19. [CrossRef]

35. Vanier, M.T.; Gissen, P.; Bauer, P.; Coll, M.J.; Burlina, A.; Hendriksz, C.J.; Latour, P.; Goizet, C.; Welford, R.W.; Marquardt, T.; et al. Diagnostic tests for Niemann-Pick disease type C (NP-C): A critical review. Mol. Genet. Metab. 2016, 118, 244-254. [CrossRef]

36. Meyer, A.; Gläser, A.; Bräuer, A.U.; Wree, A.; Strotmann, J.; Rolfs, A.; Witt, M. Olfactory performance as an indicator for protective treatment effects in an animal model of neurodegeneration. Front. Integr. Neurosci. 2018, 12, 35. [CrossRef]

37. Patterson, M.C.; Vecchio, D.; Prady, H.; Abel, L.; Wraith, J.E. Miglustat for treatment of Niemann-Pick C disease: a randomised controlled study. Lancet Neurol. 2007, 6, 765-772. [CrossRef]

38. Platt, F.M.; Jeyakumar, M. Substrate reduction therapy. Acta. Paediatr. Suppl. 2008, 97, 88-93. [CrossRef]

39. Ribas, G.S.; Pires, R.; Coelho, J.C.; Rodrigues, D.; Mescka, C.P.; Vanzin, C.S.; Biancini, G.B.; Negretto, G.; Wayhs, C.A.; Wajner, M.; et al. Oxidative stress in Niemann-Pick type C patients: a protective role of N-butyl-deoxynojirimycin therapy. Int. J. Dev. Neurosci. 2012, 30, 439-444. [CrossRef]

40. Wraith, J.E.; Vecchio, D.; Jacklin, E.; Abel, L.; Chadha-Boreham, H.; Luzy, C.; Giorgino, R.; Patterson, M.C. Miglustat in adult and juvenile patients with Niemann-Pick disease type C: long-term data from a clinical trial. Mol. Genet. Metab. 2010, 99, 351-357. [CrossRef]

41. Erickson, R.P.; Fiorenza, M.T. A hopeful therapy for Niemann-Pick C diseases. Lancet 2017, 390, $1720-1721$. [CrossRef]

42. Matsuo, M.; Togawa, M.; Hirabaru, K.; Mochinaga, S.; Narita, A.; Adachi, M.; Egashira, M.; Irie, T.; Ohno, K. Effects of cyclodextrin in two patients with Niemann-Pick Type C disease. Mol. Genet. Metab. 2013, 108, 76-81. [CrossRef]

43. Liu, B.; Ramirez, C.M.; Miller, A.M.; Repa, J.J.; Turley, S.D.; Dietschy, J.M. Cyclodextrin overcomes the transport defect in nearly every organ of NPC1 mice leading to excretion of sequestered cholesterol as bile acid. J. Lipid Res. 2010, 51, 933-944. [CrossRef]

44. Ebner, L.; Glaser, A.; Brauer, A.; Witt, M.; Wree, A.; Rolfs, A.; Frank, M.; Vollmar, B.; Kuhla, A. Evaluation of two liver treatment strategies in a mouse model of Niemann-Pick-Disease Type C1. Int. J. Mol. Sci. 2018, 19, 972. [CrossRef]

45. Crumling, M.A.; Liu, L.; Thomas, P.V.; Benson, J.; Kanicki, A.; Kabara, L.; Halsey, K.; Dolan, D.; Duncan, R.K. Hearing loss and hair cell death in mice given the cholesterol-chelating agent hydroxypropyl-beta-cyclodextrin. PLoS ONE 2012, 7, e53280. [CrossRef]

46. Vite, C.H.; Bagel, J.H.; Swain, G.P.; Prociuk, M.; Sikora, T.U.; Stein, V.M.; O’Donnell, P.; Ruane, T.; Ward, S.; Crooks, A.; et al. Intracisternal cyclodextrin prevents cerebellar dysfunction and Purkinje cell death in feline Niemann-Pick type C1 disease. Sci. Transl. Med. 2015, 7, 276ra26. [CrossRef]

47. Ory, D.S.; Ottinger, E.A.; Farhat, N.Y.; King, K.A.; Jiang, X.; Weissfeld, L.; Berry-Kravis, E.; Davidson, C.D.; Bianconi, S.; Keener, L.A.; et al. Intrathecal 2-hydroxypropyl-beta-cyclodextrin decreases neurological disease progression in Niemann-Pick disease, type C1: a non-randomised, open-label, phase 1-2 trial. Lancet 2017, 390, 1758-1768. [CrossRef] 
48. ClinicalTrials.gov. Study of VTS-270 (2-hydroxypropyl- $\beta$-cyclodextrin) to Treat Niemann-Pick Type C1 (NPC1) Disease. Available online: https:/clinicaltrials.gov/ct2/show/study/NCT02534844 (accessed on 4 September 2019).

49. Wadman, M. Update: Twins who were face of controversial rare disease treatment have died. Science 2019. [CrossRef]

50. Puskas, I. HPBCD Treatment for Niemann-Pick C: Mallinckrodt Communicated Results of Clinical Trial. Available online: https://cyclodextrinnews.com/2018/11/13/hpbcd-treatment-for-niemann-pick-type-cperformed-no-differently-than-placebo/ (accessed on 4 September 2019).

51. Davidson, C.D.; Ali, N.F.; Micsenyi, M.C.; Stephney, G.; Renault, S.; Dobrenis, K.; Ory, D.S.; Vanier, M.T.; Walkley, S.U. Chronic cyclodextrin treatment of murine Niemann-Pick C disease ameliorates neuronal cholesterol and glycosphingolipid storage and disease progression. PLoS ONE 2009, 4, e6951. [CrossRef]

52. Davidson, C.D.; Fishman, Y.I.; Puskas, I.; Szeman, J.; Sohajda, T.; McCauliff, L.A.; Sikora, J.; Storch, J.; Vanier, M.T.; Szente, L.; et al. Efficacy and ototoxicity of different cyclodextrins in Niemann-Pick C disease. Ann. Clin. Transl. Neurol. 2016, 3, 366-380. [CrossRef]

53. Hovakimyan, M.; Maass, F.; Petersen, J.; Holzmann, C.; Witt, M.; Lukas, J.; Frech, M.J.; Hubner, R.; Rolfs, A.; Wree, A. Combined therapy with cyclodextrin/allopregnanolone and miglustat improves motor but not cognitive functions in Niemann-Pick Type C1 mice. Neuroscience 2013, 252, 201-211. [CrossRef]

54. Repa, J.J.; Li, H.; Frank-Cannon, T.C.; Valasek, M.A.; Turley, S.D.; Tansey, M.G.; Dietschy, J.M. Liver X receptor activation enhances cholesterol loss from the brain, decreases neuroinflammation, and increases survival of the NPC1 mouse. J. Neurosci. 2007, 27, 14470-14480. [CrossRef]

55. Maceyka, M.; Milstien, S.; Spiegel, S. The potential of histone deacetylase inhibitors in Niemann-Pick type C disease. FEBS J. 2013, 280, 6367-6372. [CrossRef]

56. Munkacsi, A.B.; Chen, F.W.; Brinkman, M.A.; Higaki, K.; Gutierrez, G.D.; Chaudhari, J.; Layer, J.V.; Tong, A.; Bard, M.; Boone, C.; et al. An "exacerbate-reverse" strategy in yeast identifies histone deacetylase inhibition as a correction for cholesterol and sphingolipid transport defects in human Niemann-Pick type C disease. J. Biol. Chem. 2011, 286, 23842-23851. [CrossRef]

57. Pipalia, N.H.; Cosner, C.C.; Huang, A.; Chatterjee, A.; Bourbon, P.; Farley, N.; Helquist, P.; Wiest, O.; Maxfield, F.R. Histone deacetylase inhibitor treatment dramatically reduces cholesterol accumulation in Niemann-Pick type C1 mutant human fibroblasts. Proc. Natl. Acad. Sci. USA 2011, 108, 5620-5625. [CrossRef]

58. Helquist, P.; Maxfield, F.R.; Wiech, N.L.; Wiest, O. Treatment of Niemann-pick type C disease by histone deacetylase inhibitors. Neurotherapeutics 2013, 10, 688-697. [CrossRef]

59. De Ruijter, A.J.; van Gennip, A.H.; Caron, H.N.; Kemp, S.; van Kuilenburg, A.B. Histone deacetylases (HDACs): characterization of the classical HDAC family. Biochem. J. 2003, 370, 737-749. [CrossRef]

60. Newton, J.; Hait, N.C.; Maceyka, M.; Colaco, A.; Maczis, M.; Wassif, C.A.; Cougnoux, A.; Porter, F.D.; Milstien, S.; Platt, N.; et al. FTY720/fingolimod increases NPC1 and NPC2 expression and reduces cholesterol and sphingolipid accumulation in Niemann-Pick type C mutant fibroblasts. FASEB J. 2017, 31, 1719-1730. [CrossRef]

61. Hait, N.C.; Avni, D.; Yamada, A.; Nagahashi, M.; Aoyagi, T.; Aoki, H.; Dumur, C.I.; Zelenko, Z.; Gallagher, E.J.; Leroith, D.; et al. The phosphorylated prodrug FTY720 is a histone deacetylase inhibitor that reactivates ERalpha expression and enhances hormonal therapy for breast cancer. Oncogenesis 2015, 4, e156. [CrossRef]

62. Kirkegaard, T.; Roth, A.G.; Petersen, N.H.; Mahalka, A.K.; Olsen, O.D.; Moilanen, I.; Zylicz, A.; Knudsen, J.; Sandhoff, K.; Arenz, C.; et al. Hsp70 stabilizes lysosomes and reverts Niemann-Pick disease-associated lysosomal pathology. Nature 2010, 463, 549-553. [CrossRef]

63. Fog, C.K.; Kirkegaard, T. Animal models for Niemann-Pick type C: implications for drug discovery \& development. Expert Opin. Drug Discov. 2019, 14, 499-509.

64. Evans, W.R.H.; Nicoli, E.R.; Wang, R.Y.; Movsesyan, N.; Platt, F.M. Case report: Ursodeoxycholic acid treatment in Niemann-Pick disease type C; clinical experience in four cases. Wellcome Open Res. 2017, 2, 75. [CrossRef]

65. Nicoli, E.R.; Al Eisa, N.; Cluzeau, C.V.; Wassif, C.A.; Gray, J.; Burkert, K.R.; Smith, D.A.; Morris, L.; Cologna, S.M.; Peer, C.J.; et al. Defective cytochrome P450-catalysed drug metabolism in Niemann-Pick type C disease. PLoS ONE 2016, 11, e0152007. [CrossRef]

66. Bremova, T.; Malinova, V.; Amraoui, Y.; Mengel, E.; Reinke, J.; Kolnikova, M.; Strupp, M. Acetyl-dl-leucine in Niemann-Pick type C: A case series. Neurology 2015, 85, 1368-1375. [CrossRef] 
67. Xie, C.; Gong, X.M.; Luo, J.; Li, B.L.; Song, B.L. AAV9-NPC1 significantly ameliorates Purkinje cell death and behavioral abnormalities in mouse NPC disease. J. Lipid Res. 2017, 58, 512-518. [CrossRef]

68. Hughes, M.P.; Smith, D.A.; Morris, L.; Fletcher, C.; Colaco, A.; Huebecker, M.; Tordo, J.; Palomar, N.; Massaro, G.; Henckaerts, E.; et al. AAV9 intracerebroventricular gene therapy improves lifespan, locomotor function and pathology in a mouse model of Niemann-Pick type C1 disease. Hum. Mol. Genet. 2018, 27, 3079-3098. [CrossRef]

69. Chandler, R.J.; Williams, I.M.; Gibson, A.L.; Davidson, C.D.; Incao, A.A.; Hubbard, B.T.; Porter, F.D.; Pavan, W.J.; Venditti, C.P. Systemic AAV9 gene therapy improves the lifespan of mice with Niemann-Pick disease, type C1. Hum. Mol. Genet. 2017, 26, 52-64. [CrossRef]

70. Schlegel, V.; Thieme, M.; Holzmann, C.; Witt, M.; Grittner, U.; Rolfs, A.; Wree, A. Pharmacologic treatment assigned for Niemann Pick type $\mathrm{C} 1$ disease partly changes behavioral traits in wild-type mice. Int. J. Mol. Sci. 2016, 17, 1866. [CrossRef]

71. Williams, I.M.; Wallom, K.L.; Smith, D.A.; Al Eisa, N.; Smith, C.; Platt, F.M. Improved neuroprotection using miglustat, curcumin and ibuprofen as a triple combination therapy in Niemann-Pick disease type C1 mice. Neurobiol. Dis. 2014, 67, 9-17. [CrossRef]

72. King, K.A.; Gordon-Salant, S.; Yanjanin, N.; Zalewski, C.; Houser, A.; Porter, F.D.; Brewer, C.C. Auditory phenotype of Niemann-Pick disease, type C1. Ear. Hear. 2014, 35, 110-117. [CrossRef]

73. King, K.A.; Gordon-Salant, S.; Pawlowski, K.S.; Taylor, A.M.; Griffith, A.J.; Houser, A.; Kurima, K.; Wassif, C.A.; Wright, C.G.; Porter, F.D.; et al. Hearing loss is an early consequence of Npc1 gene deletion in the mouse model of Niemann-Pick disease, type C. J. Assoc. Re. Otolaryngol. 2014, 15, 529-541. [CrossRef]

74. Ward, S.; O’Donnell, P.; Fernandez, S.; Vite, C.H. 2-hydroxypropyl-beta-cyclodextrin raises hearing threshold in normal cats and in cats with Niemann-Pick type C disease. Pediatr. Res. 2010, 68, 52-56. [CrossRef]

75. Takahashi, S.; Homma, K.; Zhou, Y.; Nishimura, S.; Duan, C.; Chen, J.; Ahmad, A.; Cheatham, M.A.; Zheng, J. Susceptibility of outer hair cells to cholesterol chelator 2-hydroxypropyl-beta-cyclodextrine is prestin-dependent. Sci. Rep. 2016, 6, 21973. [CrossRef]

76. Iodice, R.; Dubbioso, R.; Topa, A.; Ruggiero, L.; Pisciotta, C.; Esposito, M.; Tozza, S.; Santoro, L.; Manganelli, F. Electrophysiological characterization of adult-onset Niemann-Pick type C disease. J. Neurol. Sci. 2015, 348, 262-265. [CrossRef]

77. Claudepierre, T.; Paques, M.; Simonutti, M.; Buard, I.; Sahel, J.; Maue, R.A.; Picaud, S.; Pfrieger, F.W. Lack of Niemann-Pick type C1 induces age-related degeneration in the mouse retina. Mol. Cell. Neurosci. 2010, 43, 164-176. [CrossRef]

78. Yan, X.; Ma, L.; Hovakimyan, M.; Lukas, J.; Wree, A.; Frank, M.; Guthoff, R.; Rolfs, A.; Witt, M.; Luo, J. Defects in the retina of Niemann-pick type C 1 mutant mice. BMC Neurosci. 2014, 15, 126. [CrossRef]

79. Palladino, G.; Loizzo, S.; Fortuna, A.; Canterini, S.; Palombi, F.; Erickson, R.P.; Mangia, F.; Fiorenza, M.T. Visual evoked potentials of Niemann-Pick type C1 mice reveal an impairment of the visual pathway that is rescued by 2-hydroxypropyl-ss-cyclodextrin. Orphanet. J. Rare Dis. 2015, 10, 133. [CrossRef]

80. Abel, L.A.; Walterfang, M.; Fietz, M.; Bowman, E.A.; Velakoulis, D. Saccades in adult Niemann-Pick disease type C reflect frontal, brainstem, and biochemical deficits. Neurology 2009, 72, 1083-1086. [CrossRef]

81. Hovakimyan, M.; Meyer, A.; Lukas, J.; Luo, J.; Gudziol, V.; Hummel, T.; Rolfs, A.; Wree, A.; Witt, M. Olfactory deficits in Niemann-Pick type C1 (NPC1) disease. PLoS ONE 2013, 8, e82216. [CrossRef]

82. Seo, Y.; Kim, H.S.; Shin, Y.; Kang, I.; Choi, S.W.; Yu, K.R.; Seo, K.W.; Kang, K.S. Excessive microglial activation aggravates olfactory dysfunction by impeding the survival of newborn neurons in the olfactory bulb of Niemann-Pick disease type C1 mice. Biochim. Biophys. Acta. 2014, 1842, 2193-2203. [CrossRef]

83. Meyer, A.; Wree, A.; Günther, R.; Holzmann, C.; Schmitt, O.; Rolfs, A.; Witt, M. Increased regenerative capacity of the olfactory epithelium in Niemann-Pick disease type C1. Int. J. Mol. Sci. 2017, $18,777$. [CrossRef]

84. Bagel, J.H.; Sikora, T.U.; Prociuk, M.; Pesayco, J.P.; Mizisin, A.P.; Shelton, G.D.; Vite, C.H. Electrodiagnostic testing and histopathologic changes confirm peripheral nervous system myelin abnormalities in the feline model of niemann-pick disease type C. J. Neuropathol. Exp. Neurol. 2013, 72, 256-262. [CrossRef]

85. Marmiroli, P.; Rodriguez-Menendez, V.; Rigamonti, L.; Tonoli, E.; Rigolio, R.; Cavaletti, G.; Tredici, G.; Vercelli, A. Neuropathological changes in the peripheral nervous system and spinal cord in a transgenic mouse model of Niemann-Pick disease type A. Clin. Neuropathol. 2009, 28, 263-274. 
86. Donohue, C.; Marion, S.; Erickson, R.P. Expression of Npc1 in glial cells corrects sterility in Npc1(-/-) mice. J. Appl. Genet. 2009, 50, 385-390. [CrossRef]

87. Gevry, N.Y.; Lopes, F.L.; Ledoux, S.; Murphy, B.D. Aberrant intracellular cholesterol transport disrupts pituitary and ovarian function. Molecul. Endocrinol. 2004, 18, 1778-1786. [CrossRef]

88. Akpovi, C.D.; Murphy, B.D.; Erickson, R.P.; Pelletier, R.M. Dysregulation of testicular cholesterol metabolism following spontaneous mutation of the niemann-pick c1 gene in mice. Biol. Reprod. 2014, 91, 42. [CrossRef]

89. Roff, C.F.; Strauss, J.F., 3rd; Goldin, E.; Jaffe, H.; Patterson, M.C.; Agritellis, G.C.; Hibbs, A.M.; Garfield, M.; Brady, R.O.; Pentchev, P.G. The murine Niemann-Pick type C lesion affects testosterone production. Endocrinology 1993, 133, 2913-2923. [CrossRef]

90. Fan, J.; Akabane, H.; Graham, S.N.; Richardson, L.L.; Zhu, G.Z. Sperm defects in mice lacking a functional Niemann-Pick C1 protein. Mol. Reprod. Dev. 2006, 73, 1284-1291. [CrossRef]

91. Elleder, M.; Šmíd, F. Adrenal changes in Niemann-Pick disease: Differences between sphingomyelinase deficiency and type C. Acta. Histochemica. 1985, 76, 163-176. [CrossRef]

92. Kapur, R.; Donohue, C.; Jelinek, D.; Erickson, R.P. Amelioration of enteric neuropathology in a mouse model of Niemann-Pick C by Npc1 expression in enteric glia. J. Neurosci. Res. 2009, 87, 2994-3001. [CrossRef]

93. Cougnoux, A.; Movassaghi, M.; Picache, J.A.; Iben, J.R.; Navid, F.; Salman, A.; Martin, K.; Farhat, N.Y.; Cluzeau, C.; Tseng, W.C.; et al. Gastrointestinal tract pathology in a BALB/c Niemann-Pick disease type C1 null mouse model. Dig. Dis. Sci. 2018, 63, 870-880. [CrossRef]

94. Cavounidis, A.; Uhlig, H.H. Crohn's disease in Niemann-Pick disease type C1: Caught in the cross-Fire of host-microbial interactions. Dig. Dis. Sci. 2018, 63, 811-813. [CrossRef]

95. Schwerd, T.; Pandey, S.; Yang, H.T.; Bagola, K.; Jameson, E.; Jung, J.; Lachmann, R.H.; Shah, N.; Patel, S.Y.; Booth, C.; et al. Impaired antibacterial autophagy links granulomatous intestinal inflammation in Niemann-Pick disease type C1 and XIAP deficiency with NOD2 variants in Crohn's disease. Gut 2017, 66, 1060-1073. [CrossRef]

96. Steven, L.C.; Driver, C.P. Niemann-pick disease type C and Crohn's disease. Scott. Med. J. 2005, 50, 80-81. [CrossRef]

97. Hammel, I.; Alroy, J. The effect of lysosomal storage diseases on secretory cells: An ultrastructural study of pancreas as an example. J. Submicrosc. Cytol. Pathol. 1995, 27, 143-160.

98. Staretz-Chacham, O.; Aviram, M.; Morag, I.; Goldbart, A.; Hershkovitz, E. Pulmonary involvement in Niemann-Pick C type 1. Eur. J. Pediatr. 2018. [CrossRef]

99. Roszell, B.R.; Tao, J.Q.; Yu, K.J.; Gao, L.; Huang, S.; Ning, Y.; Feinstein, S.I.; Vite, C.H.; Bates, S.R. Pulmonary abnormalities in animal models due to Niemann-Pick type C1 (NPC1) or C2 (NPC2) disease. PLoS ONE 2013, 8, e67084. [CrossRef]

100. Erickson, R.P.; Deutsch, G.; Patil, R. A pilot study of direct delivery of hydroxypropyl-beta-cyclodextrin to the lung by the nasal route in a mouse model of Niemann-Pick $\mathrm{C} 1$ disease: motor performance is unaltered and lung disease is worsened. J. Appl. Genet. 2018, 59, 187-191. [CrossRef]

101. Capron, T.; Trigui, Y.; Gautier, C.; Puech, B.; Chanez, P.; Reynaud-Gaubert, M. Respiratory impairment in Niemann-Pick B disease: Two case reports and review for the pulmonologist. Respir. Med. Res. 2019, 76, 13-18. [CrossRef]

102. Kuemmel, T.A.; Thiele, J.; Schroeder, R.; Stoffel, W. Pathology of visceral organs and bone marrow in an acid sphingomyelinase deficient knock-out mouse line, mimicking human Niemann-Pick disease type A. A light and electron microscopic study. Pathol. Res. Pract. 1997, 193, 663-671. [CrossRef]

103. Pitha, J.; Gerloczy, A.; Olivi, A. Parenteral hydroxypropyl cyclodextrins: intravenous and intracerebral administration of lipophiles. J. Pharm. Sci. 1994, 83, 833-837. [CrossRef]

104. Reif, S.; Spirer, Z.; Messer, G.; Baratz, M.; Bembi, B.; Bujanover, Y. Severe failure to thrive and liver dysfunction as the main manifestations of a new variant of Niemann-Pick disease. Clin. Pediatr. (Phila) 1994, 33, 628-630. [CrossRef]

105. Putterman, C.; Zelingher, J.; Shouval, D. Liver failure and the sea-blue histiocyte/adult Niemann-Pick disease. Case report and review of the literature. J. Clin. Gastroenterol. 1992, 15, 146-149. [CrossRef]

106. Rutledge, J.C. Progressive neonatal liver failure due to type C Niemann-Pick isease. Pediatr. Pathol. 1989, 9 , 779-784. [CrossRef] 
107. Dumontel, C.; Girod, C.; Dijoud, F.; Dumez, Y.; Vanier, M.T. Fetal Niemann-Pick disease type C: ultrastructural and lipid findings in liver and spleen. Virchows Arch. A Pathol. Anat. Histopathol. 1993, 422, 253-259. [CrossRef]

108. Yerushalmi, B.; Sokol, R.J.; Narkewicz, M.R.; Smith, D.; Ashmead, J.W.; Wenger, D.A. Niemann-pick disease type C in neonatal cholestasis at a North American Center. J. Pediatr. Gastroenterol. Nutr. 2002, 35, 44-50. [CrossRef]

109. Beltroy, E.P.; Richardson, J.A.; Horton, J.D.; Turley, S.D.; Dietschy, J.M. Cholesterol accumulation and liver cell death in mice with Niemann-Pick type C disease. Hepatology 2005, 42, 886-893. [CrossRef]

110. Rimkunas, V.M.; Graham, M.J.; Crooke, R.M.; Liscum, L. TNF-(alpha) plays a role in hepatocyte apoptosis in Niemann-Pick type C liver disease. J. Lipid Res. 2009, 50, 327-333. [CrossRef]

111. Sayre, N.L.; Rimkunas, V.M.; Graham, M.J.; Crooke, R.M.; Liscum, L. Recovery from liver disease in a Niemann-Pick type C mouse model. J. Lipid Res. 2010, 51, 2372-2383. [CrossRef]

112. Jelinek, D.; Castillo, J.J.; Garver, W.S. The C57BL/6J Niemann-Pick C1 mouse model with decreased gene dosage has impaired glucose tolerance independent of body weight. Gene 2013, 527, 65-70. [CrossRef]

113. Li, A.C.; Glass, C.K. PPAR- and LXR-dependent pathways controlling lipid metabolism and the development of atherosclerosis. J. Lipid Res. 2004, 45, 2161-2173. [CrossRef]

114. Tanaka, Y.; Yamada, Y.; Ishitsuka, Y.; Matsuo, M.; Shiraishi, K.; Wada, K.; Uchio, Y.; Kondo, Y.; Takeo, T.; Nakagata, N.; et al. Efficacy of 2-hydroxypropyl-beta-cyclodextrin in Niemann-Pick disease type C model mice and its pharmacokinetic analysis in a patient with the disease. Biol. Pharm. Bull. 2015, 38, 844-851. [CrossRef]

115. Rigante, D.; Cipolla, C.; Basile, U.; Gulli, F.; Savastano, M.C. Overview of immune abnormalities in lysosomal storage disorders. Immunol. Lett. 2017, 188, 79-85. [CrossRef]

116. Nesslauer, A.M.; Gläser, A.; Gräler, M.; Engelmann, R.; Müller-Hilke, B.; Frank, M.; Burstein, C.; Rolfs, A.; Neidhardt, J.; Wree, A.; et al. A therapy with miglustat, 2-hydroxypropyl-ss-cyclodextrin and allopregnanolone restores splenic cholesterol homeostasis in Niemann-pick disease type C1. Lipids Health Dis. 2019, 18, 146. [CrossRef]

117. Angheloiu, G.O.; Haka, A.S.; Georgakoudi, I.; Arendt, J.; Muller, M.G.; Scepanovic, O.R.; Evanko, S.P.; Wight, T.N.; Mukherjee, P.; Waldeck, D.H.; et al. Detection of coronary atherosclerotic plaques with superficial proteoglycans and foam cells using real-time intrinsic fluorescence spectroscopy. Atherosclerosis 2011, 215, 96-102. [CrossRef]

118. O’Brien, K.D.; Gordon, D.; Deeb, S.; Ferguson, M.; Chait, A. Lipoprotein lipase is synthesized by macrophage-derived foam cells in human coronary atherosclerotic plaques. J. Clin. Invest. 1992, 89, 1544-1550. [CrossRef]

119. Dubland, J.A.; Francis, G.A. So much cholesterol: the unrecognized importance of smooth muscle cells in atherosclerotic foam cell formation. Curr. Opin. Lipidol. 2016, 27, 155-161. [CrossRef]

120. Coisne, C.; Hallier-Vanuxeem, D.; Boucau, M.C.; Hachani, J.; Tilloy, S.; Bricout, H.; Monflier, E.; Wils, D.; Serpelloni, M.; Parissaux, X.; et al. Beta-cyclodextrins decrease cholesterol release and ABC-associated transporter expression in smooth muscle cells and aortic endothelial cells. Front. Physiol. 2016, 7, 185. [CrossRef]

121. Montecucco, F.; Lenglet, S.; Carbone, F.; Boero, S.; Pelli, G.; Burger, F.; Roth, A.; Bertolotto, M.; Nencioni, A.; Cea, M.; et al. Treatment with KLEPTOSE(R) CRYSMEB reduces mouse atherogenesis by impacting on lipid profile and Th1 lymphocyte response. Vascul. Pharmacol. 2015, 72, 197-208. [CrossRef]

122. Zimmer, S.; Grebe, A.; Bakke, S.S.; Bode, N.; Halvorsen, B.; Ulas, T.; Skjelland, M.; De Nardo, D.; Labzin, L.I.; Kerksiek, A.; et al. Cyclodextrin promotes atherosclerosis regression via macrophage reprogramming. Sci. Transl. Med. 2016, 8, 333ra50. [CrossRef]

123. Mesquita-Guimaraes, K.S.; De Rossi, A.; Freitas, A.C.; Nelson-Filho, P.; da Silva, R.A.; de Queiroz, A.M. Changes in caries risk and activity of a 9-year-old patient with niemann-pick disease type C. Case Rep. Dent. 2015, 2015, 571098. [CrossRef]

(C) 2019 by the authors. Licensee MDPI, Basel, Switzerland. This article is an open access article distributed under the terms and conditions of the Creative Commons Attribution (CC BY) license (http://creativecommons.org/licenses/by/4.0/). 